\title{
Analysis on Influencing Elements of Enterprise Logistics Risk Early Warning: Based on Manufacturing Industries in Beijing Area*
}

\author{
Yongsheng Liu, Rong Yu \\ School of Business, Beijing Wuzi University, Beijing, China. \\ Email: bjwylys@sina.com, yurongnick@sina.com \\ Received May $26^{\text {th }}, 2013$; revised June $26^{\text {th }}, 2013$; accepted July $16^{\text {th }}, 2013$ \\ Copyright (C) 2013 Yongsheng Liu, Rong Yu. This is an open access article distributed under the Creative Commons Attribution Li- \\ cense, which permits unrestricted use, distribution, and reproduction in any medium, provided the original work is properly cited.
}

\begin{abstract}
Enterprise logistics risk early warning is an essential part of enterprise logistics risk management, which has been increasingly drawing the attentions of both practical and academic world. However, enterprise logistics risk early warning hasn't been radically put into practice yet. Therefore, the factors hinder the proceeding of enterprise logistics risk early warning become the key to starting the engine of enterprise logistics risk early warning. In this paper, review of researches on enterprise logistics risk early warning is provided, a questionnaire has been designed according to both exterior and internal factors influencing enterprise logistics risk early warning and a survey on manufacturing industries in Beijing area has been carried out, logistics risk early warning status and influencing elements have been analyzed based on previous survey and advices proposed are concluded to provide valuable references.
\end{abstract}

Keywords: Enterprise Logistics; Risk Early Warning; Influencing Elements

\section{Preface}

In China, enterprise logistics risk has not gained sufficient watch due to the ignorance of perception of risk among corporate management and inability of risk control, which contributes to the outbreak of enterprise risk accidents and increases that probability. It's proved true that effectiveness achieved by prevention work before the outbreak of risk accidents outweighs that of postaccident emergency management, hence the significance of enterprise logistics risk early warning. Both practical and academic world should pay attention to related researches.

\section{Status Quo of Researches on Enterprise Logistics Risk Early Warning}

So far, related researches on enterprise logistics risk early warning mainly focus on logistics service risk, outsourcing risk, reverse logistics and enterprise logistics, but the empirical researches seldom appear.

\footnotetext{
${ }^{*}$ This work is supported by Project supported by the Philosophy and Social Science Planning of Beijing (Grant No. 11JGB053) and Project supported by Academic Human Resources Development in Institutions of Higher Learning under the Jurisdiction of Beijing Municipality (PHR (IHLB)) under (Grant No. PHR2012).
}

Liu (2007) [1] applied fuzzy comprehensive evaluation method to logistics service risk early warning management, formulating an index system of logistics service risk early warning and predicting logistics service risk status in both single early warning mode and comprehendsive early warning mode, and provide a set of warning signals match with logistics service risk classification. Q. Cheng (2010) [2] analyzed causes of formation of logistics service operation risk according to the connotetion and categories of logistics service operation risk, and discussed the methodologies, models, substances and requirements of early warning, also provided an index system and some strategies of logistics service operation risk early warning. Y. S. Liu et al. (2010) [3] analyzed causing factors of risk during supply chain logistics service of logistics corporations, designing a corporate logistics risk early warning index system based on balance score card, and applied fuzzy evaluation-AHP to logistics corporations risk early warning.

L. H. Liu (2005) [4] conducted a preliminary design of logistics outsourcing, integrating fuzzy comprehensive evaluation method with outsourcing risk evaluation. G. B. $\mathrm{Xu}$ (2007) [5] proposed a method of corporate logistics outsourcing risk early warning based on case reasoning, 
applying analogical reasoning method to corporate logistics outsourcing risk early warning. Y. T. Hong et al. (2008) [6] analyzed corporate logistics outsourcing risk, and created a corresponding index system.

D. H. Yang et al. (2008) [7] designed an evaluation index system of reverse logistics risk early warning. W. Y. Duan (2010) [8] established reverse logistics risk early warning system, utilizing MATLAB tool kit to build up corporate reverse logistics risk early warning model and to prove BP neural network absolutely fit reverse logistics risk early warning model.

M. Q. Zhang et al. (2008) [9] analyzed risk types and causes of each basic logistics activity, and set up an early warning index system of activity risk, discussing the operation management mechanism of risk early warning. Xie et al. (2009) [10] researched into internal logistics early warning management of middle and small businesses based on tag card system, through which overall operation procedures, quality and quantity can be supervised in a dynamic way, which can improve the early warning and control system. Y. S. Liu et al. (2009) [11] analyzed the concept of corporate risk early warning and causes and signs of corporate logistics, discussed enterprise logistics risk early warning mechanism based on supply chain management. Cheng et al. (2010) [12] researched in logistics balance early warning of steel industries ports, discussing methodologies of raw material inventory early warning, achieving logistics balance and matching industry port raw material with internal raw material supplying logistics. L. Ji (2010) [13] applied forced decision method to China's corporate logistics risk level, and fuzzy comprehensive evaluation to postrisk effectiveness degree, and concluded the corresponding evaluation classification according to the data acquired by on-site researches, offering enterprises beneficial references of logistics risk early warning work.

Above researches mainly utilize normative research method, discussing logistics risk early warning at the enterprise level, which contributes little to improve logistics risk early warning. This paper utilized investigation and statistics analysis to analyze influencing elements of corporate logistics risk based on previous researching results, aiming to provide more scientific references to improvement of enterprise logistics risk early warning.

\section{Methodology and Design}

\subsection{Research Route}

Firstly through analyzing references, influencing elements of enterprise logistics risk early warning are concluded. Then though surveying manufacturing enterprises in Beijing area by questionnaires, the perception status of corporate logistics risk influencing elements of staffs of each level in manufacturing enterprises are summed up. At last, SPSS software is used to carry out quantitative analysis so as to calculate the related significance of those influencing elements to enterprise logistics risk early warning. SPSS software is used to calculate weights of each influencing factor in this research.

\subsection{Design of Investigation Content}

Based on analysis on references and preliminary investigation, investigation content in questionnaire is divided into two parts: one is about basic status of enterprise logistics risk early warning, the other is focusing on influencing elements.

Basic status of enterprise logistics risk early warning includes: 1) how do objects know about enterprise logistics risk early warning. 2) Whether enterprises surveyed take any measures of logistics risk early warning. 3) Whether enterprises surveyed offer staff training on risk early warning. 4) Relations among goal hit rate of enterprises' logistics risk early warning and degree of perception of risk early warning of staffs and effectiveness of risk early warning activities. 5) As for enterprise logistics risk early warning, which of below items should be solved (multiple choices allowed)?

1) How to identify and evaluate logistics risk.

2) To understand the content of logistics risk early warning process.

3) How to select proper index of enterprise logistics risk early warning.

4) To understand the organizing procedure of enterprise logistics risk early warning.

5) Others (please explain in detail).

The influencing elements of enterprise logistics risk early warning are illustrated in Table 1.

Table 1. Influencing elements of enterprise logistics risk early warning.

\begin{tabular}{cc}
\hline External factors & Internal factors \\
\hline $\begin{array}{c}\text { Uncertainty of natural } \\
\text { environment }\end{array}$ & Emphasis put by senior executives \\
$\begin{array}{c}\text { Uncertainty of political } \\
\text { environment }\end{array}$ & $\begin{array}{c}\text { Qualification of staffs in risk } \\
\text { management }\end{array}$ \\
$\begin{array}{c}\text { Uncertainty of legal } \\
\text { environment } \\
\text { Uncertainty of economic } \\
\text { environment }\end{array}$ & $\begin{array}{c}\text { Logistics management level } \\
\text { Improvement of logistics risk } \\
\text { management institutions }\end{array}$ \\
& $\begin{array}{c}\text { Advancement of logistics risk } \\
\text { management technology }\end{array}$ \\
& \begin{tabular}{c} 
Logistics development phase \\
\hline
\end{tabular}
\end{tabular}




\subsection{Research Object}

In this research, Beijing area as a benchmark in the development of corporate logistics is selected as research geographic scale, and the manufacturing corporates are chosen as research objects, which refer to electronic manufacturing industry, electro-mechanics manufacturing industry, transportation manufacturing industry and pharmaceutical manufacturing industry. The researching investigation requires objects should work in different departments, including purchasing, production, sales, logistics and finance, and work in different levels, including first-line staff, supervisor, middle manager and senior executives. Thus an inclusive and convinced result can be showed.

\subsection{Questionnaire Survey and Result Analysis}

200 questionnaires have been handed out, 183 of which have been retrieved. With incomplete 3 deducted, the final sum of effective retrieved questionnaire is $180,90 \%$ of hand-out.

1) Description of objects

Based on 180 effective retrieved questionnaires, male to female ratio is $38.3: 61.7$. Basic information of objects is showed in Table 2.

2) Reliability analysis

The Cronbach Alpha coefficient in SPSS software is used to testify reliability of questionnaires. 10 influencing elements of enterprise logistics risk early warning are of acceptable criteria, with the Cronbach Alpha coefficient of 0.763 , higher than 0.7 , which manifests that the questionnaires are well-reliable.

\section{Analysis on Basic Status of Enterprise Logistics Risk Early Warning}

After analyzing 180 effective questionnaires, basic status of enterprise logistics risk early warning of manufacturing corporations in Beijing area is obtained, as shown in Table 3, from which the followings can be explicitly concluded.

1) Enterprises have insufficient understanding of logistics risk early warning. As investigation result shows, $63.33 \%$ objects have no or little understanding of enterprise logistics risk early warning, with the comparison that only $8.34 \%$ know or pretty know this concept, which indicates that knowledge of enterprise logistics risk early warning need to be popularized. $71.67 \%$ corporations surveyed take no measures of enterprise logistics risk early warning. As for training on risk early warning, $73.89 \%$ corporations have no trainings on risk early warning, let alone enterprise logistics risk early warning. It can be seen that corporations attach less importance to logistics risk early warning, which need to be solved.

2) To achieve the goal set by enterprise logistics risk early warning, rich knowledge of enterprise logistics risk early warning and beneficial effectiveness of risk early warning is required. As research indicates, $47.78 \%$ objects think that corporations are not qualified in risk early warning has (a lot) to do with their knowledge and effectiveness of warning activities, while only $16.11 \%$ don't think so. Therefore corporations that are intend to achieve the goals set by enterprise logistics risk early warning need to improve two things, which one is strengthening related training, the other is improving the effectiveness of risk early warning activities.

3) As for knowledge of enterprise logistics risk early warning, the content of enterprise logistics risk early warning process and selection of index does really matter. Seen from research result, $39.44 \%$ objects think that understanding of the content of enterprise logistics risk early warning process is important, $28.33 \%$ think that selection of risk early warning index should be put on emphasis, $20.56 \%$ think that understanding of organizing procedure of enterprise logistics risk early warning is essential, and $20 \%$ think that identifying and evaluating enterprise logistics risk is critical. Besides, a small proportion of objects put inclusive and systematic training offered to staffs should be improved.

Table 2. Basic information of objects.

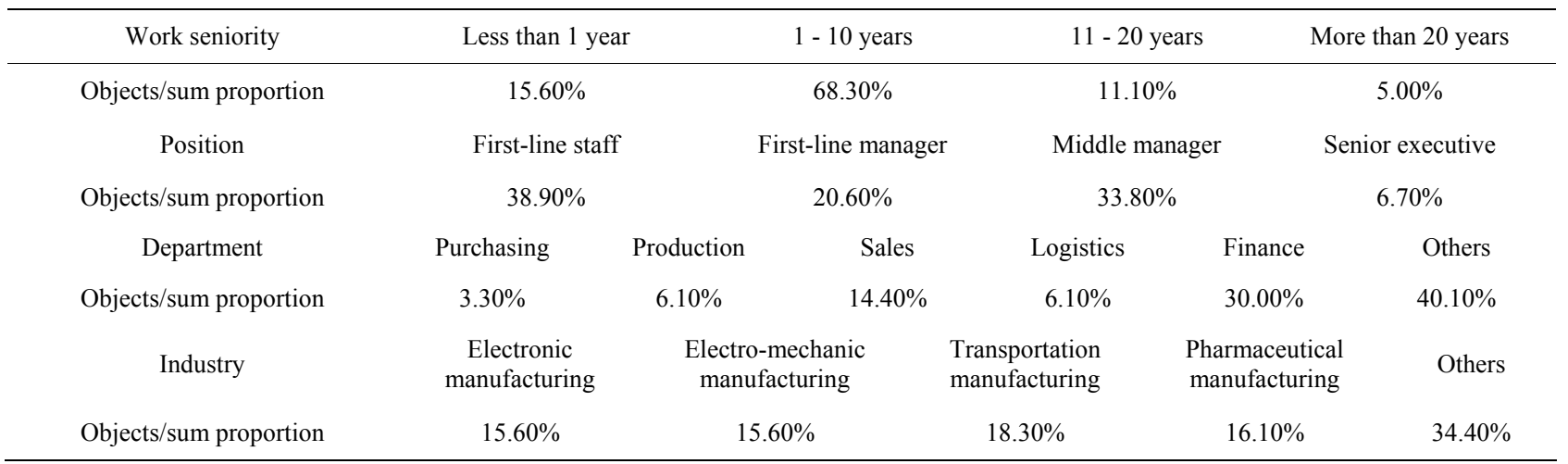


Table 3. Basic status of enterprise logistics risk early warning.

\begin{tabular}{|c|c|c|c|}
\hline Question & Choice & Sample & Percentage \\
\hline \multirow{5}{*}{$\begin{array}{l}\text { Degree of understanding of enterprise logistics } \\
\text { risk early warning }\end{array}$} & Expert & 5 & $2.78 \%$ \\
\hline & Understand it & 10 & $5.56 \%$ \\
\hline & Know about it & 51 & $28.33 \%$ \\
\hline & Know less about it & 65 & $36.11 \%$ \\
\hline & Do not know & 49 & $27.22 \%$ \\
\hline \multirow{3}{*}{$\begin{array}{l}\text { Whether corporations take measures of } \\
\text { enterprise logistics risk early warning }\end{array}$} & Yes & 42 & $23.33 \%$ \\
\hline & Yes, but not of logistics risk & 9 & $5.00 \%$ \\
\hline & No & 129 & $71.67 \%$ \\
\hline \multirow{3}{*}{$\begin{array}{c}\text { Whether corporations offer trainings on risk } \\
\text { early warning }\end{array}$} & Yes. Specially & 13 & $7.22 \%$ \\
\hline & Yes. But not specially & 34 & $18.89 \%$ \\
\hline & No & 133 & $73.89 \%$ \\
\hline \multirow{5}{*}{$\begin{array}{l}\text { Relation between corporation's hit rate of } \\
\text { logistics risk early warning and richness degree } \\
\text { of knowledge and effectiveness of risk early } \\
\text { warning activities }\end{array}$} & Significant & 31 & $17.22 \%$ \\
\hline & Near significant & 55 & $30.56 \%$ \\
\hline & Modest significant & 65 & $36.11 \%$ \\
\hline & Insignificant & 14 & $7.78 \%$ \\
\hline & Not at all & 15 & $8.33 \%$ \\
\hline \multirow{5}{*}{$\begin{array}{l}\text { As for enterprise logistics risk early warning, } \\
\text { problems need be solved in terms of mastering } \\
\text { knowledge of risk early warning (multiple } \\
\text { choices allowed) }\end{array}$} & $\begin{array}{l}\text { How to identify and evaluate enterprise logistics } \\
\text { risk }\end{array}$ & 36 & $20.00 \%$ \\
\hline & $\begin{array}{l}\text { Understanding of the content of enterprise } \\
\text { logistics risk early warning process }\end{array}$ & 71 & $39.44 \%$ \\
\hline & How to select proper index & 51 & $28.33 \%$ \\
\hline & $\begin{array}{l}\text { Understanding of organizing procedure of } \\
\text { enterprise logistics risk early warning }\end{array}$ & 37 & $20.56 \%$ \\
\hline & $\begin{array}{l}\text { Others (such as systematic knowledge of } \\
\text { enterprise logistics risk) }\end{array}$ & 3 & $1.67 \%$ \\
\hline
\end{tabular}

\section{Analysis on Influencing Index of Enterprise Logistics Risk Early Warning}

\subsection{Analysis on Information of Influencing Index of Enterprise Logistics Risk Early Warning}

Based on 180 effective questionnaires, categorized by external and internal influencing elements of enterprise logistics risk early warning and their effects, basic information of influencing elements come into being, shown as Table 4.

Seen from Table 4, although external factors have different effects on enterprise logistics risk, less objects don't think external factors have radical effects, with $22.64 \%$ think the effects are slight and $31.66 \%$, significant. Mostly, $45.70 \%$ objects think the effects are just mild. More detailed information of each external factor's character can be found in Table 4.

Unlike perception of external factors, most objects consider internal factors have significant effects on enterprise logistics risk early warning, with the total of $61.67 \%$, and only $4.81 \%$ consider that effects are slight.
Among the rest, $33.52 \%$ think that effects are modest. What's more, three internal factors including attention attached by senior executives, logistics management level and quality of staff are considered that have tremendous effects by respectively $75 \%, 76.67 \%$ and $69.45 \%$ objects.

\subsection{Factor Analysis of Influencing Elements of Enterprise Logistics Risk Early Warning}

1) Factor analysis of external influencing elements

Factor analysis function in SPSS software is utilized to conduct quantitative analysis on external influencing elements of enterprise logistics risk early warning. Results are showed in Tables 5-7.

Seen from Table 5, KMO value of external influencing elements is 0.660 , higher than 0.5, and Bartlett test value, sig. $=0.000$. The relation among variables is insignificant, hence the factor analysis.

Concluded from Tables 6 and 7, four external influencing elements including natural environment, legal environment, political environment and economic environment can be represented $86.211 \%$ by 3 factors 
Table 4. Basic information of influencing elements of enterprise logistics risk early warning.

\begin{tabular}{|c|c|c|c|}
\hline Question & Choice & Sample & Percentage \\
\hline \multirow{5}{*}{$\begin{array}{l}\text { Degree of understanding of enterprise logistics } \\
\text { risk early warning }\end{array}$} & Expert & 5 & $2.78 \%$ \\
\hline & Understand it & 10 & $5.56 \%$ \\
\hline & Know about it & 51 & $28.33 \%$ \\
\hline & Know less about it & 65 & $36.11 \%$ \\
\hline & Do not know & 49 & $27.22 \%$ \\
\hline \multirow{3}{*}{$\begin{array}{l}\text { Whether corporations take measures of } \\
\text { enterprise logistics risk early warning }\end{array}$} & Yes & 42 & $23.33 \%$ \\
\hline & Yes, but not of logistics risk & 9 & $5.00 \%$ \\
\hline & No & 129 & $71.67 \%$ \\
\hline \multirow{3}{*}{$\begin{array}{c}\text { Whether corporations offer trainings on risk } \\
\text { early warning }\end{array}$} & Yes. Specially & 13 & $7.22 \%$ \\
\hline & Yes. But not specially & 34 & $18.89 \%$ \\
\hline & No & 133 & $73.89 \%$ \\
\hline \multirow{5}{*}{$\begin{array}{l}\text { Relation between corporation's hit rate of } \\
\text { logistics risk early warning and richness degree } \\
\text { of knowledge and effectiveness of risk early } \\
\text { warning activities }\end{array}$} & Significant & 31 & $17.22 \%$ \\
\hline & Near significant & 55 & $30.56 \%$ \\
\hline & Modest significant & 65 & $36.11 \%$ \\
\hline & Insignificant & 14 & $7.78 \%$ \\
\hline & Not at all & 15 & $8.33 \%$ \\
\hline \multirow{5}{*}{$\begin{array}{l}\text { As for enterprise logistics risk early warning, } \\
\text { problems need be solved in terms of mastering } \\
\text { knowledge of risk early warning (multiple } \\
\text { choices allowed) }\end{array}$} & $\begin{array}{c}\text { How to identify and evaluate enterprise logistics } \\
\text { risk }\end{array}$ & 36 & $20.00 \%$ \\
\hline & $\begin{array}{l}\text { Understanding of the content of enterprise } \\
\text { logistics risk early warning process }\end{array}$ & 71 & $39.44 \%$ \\
\hline & How to select proper index & 51 & $28.33 \%$ \\
\hline & $\begin{array}{l}\text { Understanding of organizing procedure of } \\
\text { enterprise logistics risk early warning }\end{array}$ & 37 & $20.56 \%$ \\
\hline & $\begin{array}{l}\text { Others (such as systematic knowledge of } \\
\text { enterprise logistics risk) }\end{array}$ & 3 & $1.67 \%$ \\
\hline
\end{tabular}

Table 5. KMO and Bartlett's Test on external influencing elements.

\begin{tabular}{ccc}
\hline \multicolumn{2}{c}{ Kaiser-Meyer-Olkin Measure of Sampling Adequacy. } & 0.660 \\
\hline & Approx. Chi-Square & 78.030 \\
Bartlett's Test of Sphericity & df & 6 \\
& Sig. & 0.000 \\
\hline
\end{tabular}

Table 6. Total variance explained by external influencing elements.

\begin{tabular}{cccccccccc}
\hline \multirow{2}{*}{ Component } & \multicolumn{3}{c}{ Initial eigenvalue } & \multicolumn{2}{c}{ Extracted sum of squares loaded } & \multicolumn{3}{c}{ rotated sum of squares loaded } \\
\cline { 2 - 10 } & Sum & Variance \% & Accumulated \% & Sum & Variance \% & Accumulated \% & Sum & Variance \% & Accumulated \% \\
\hline 1 & 1.845 & 46.128 & 46.128 & 1.845 & 46.128 & 46.128 & 1.316 & 32.905 & 32.905 \\
2 & 0.905 & 22.616 & 68.745 & 0.905 & 22.616 & 68.745 & 1.098 & 27.444 & 60.349 \\
3 & 0.699 & 17.466 & 86.211 & 0.699 & 17.466 & 86.211 & 1.034 & 25.862 & 86.211 \\
4 & 0.552 & 13.789 & 100.000 & & & & & & \\
\hline
\end{tabular}

Table 7. Matrix of rotated components of external influencing elements.

\begin{tabular}{lccc}
\hline Influencing elements & \multicolumn{3}{c}{ Component } \\
\cline { 2 - 4 } & 1 & 2 & 3 \\
\hline Degree of effect of natural environment on risk early warning & 0.084 & 0.964 & 0.038 \\
Degree of effect of natural environment on risk early warning & 0.650 & 0.405 & 0.266 \\
Degree of effect of natural environment on risk early warning & 0.924 & -0.021 & 0.103 \\
Degree of effect of natural environment on risk early warning & 0.182 & 0.055 & 0.976 \\
\hline
\end{tabular}


extracted. First factor represents degree of effect of legal and political environmental change on enterprise logistics risk early warning. Second, level of effect of uncertainty of natural environment on enterprise logistics risk early warning. Third, level of effect of uncertainty of economic environment on enterprise logistics risk early warning. Therefore, three new factors can be extracted as political-legal environment factor, natural environment factor and economic environment factor.

To control external influencing elements, those three new extracted factors can be used to simplify the surveillance on enterprise logistics operation process. In practice, to enhance the efficiency of logistics risk early warning, updated political-legal disciplines and all kinds of environmental information such as weather forecast should be considered at all times, also international economic environment should be paid attention to grasp the initiative.

2) Factor analysis on internal influencing elements

Factor analysis function in SPSS software is utilized to conduct quantitative analysis on internal influencing elements of enterprise logistics risk early warning. Results are showed in Tables 8-10.

Seen from Table 8, KMO value of internal influencing elements is 0.774 , higher than 0.7 , and Bartlett test value, sig. $=0.000$. The relation among variables is insignificant, hence the factor analysis.

Concluded from Table 9, internal influencing elements can be represented $87.780 \%$ by 4 factors extracted.
First factor represents quality of logistics risk management staffs and logistics management level. Second, improvement of logistics risk management institutions and advancement of logistics risk management technology. Third represents degree of effect of logistics development phase. Forth represents degree of effect of attention attached by senior executives. Therefore, four new factors extracted can be defined as logistics management soft technology, logistics management hard technology, phase of logistics development and attention attached by senior executives.

While controlling internal influencing elements, those four new extracted factors can be used to simplify the effectiveness of enterprise logistics risk early warning. As for logistics management soft technology, one of four new extracted factors, it refers to enhancement of quality of staffs of enterprise logistics risk management, such as strengthening trainings. Due to the requirement of logistics management hard technology, enterprise ought to carry out new R\&D or import new logistics software and

Table 8. KMO and Bartlett's Test on internal influencing elements.

\begin{tabular}{lcc}
\hline Kaiser-Meyer-Olkin Measure of Sampling Adequacy. & 0.774 \\
& Approx. Chi-Square & 322.435 \\
Bartlett's Test of Sphericity & df & 15 \\
& Sig. & 0.000 \\
\hline
\end{tabular}

Table 9. Total variance explained by internal influencing elements.

\begin{tabular}{|c|c|c|c|c|c|c|c|c|c|}
\hline \multirow{2}{*}{ Component } & \multicolumn{3}{|c|}{ Initial eigenvalue } & \multicolumn{3}{|c|}{ Extracted sum of squares loaded } & \multicolumn{3}{|c|}{ rotated sum of squares loaded } \\
\hline & Sum & Variance $\%$ & Accumulated $\%$ & Sum & Variance $\%$ & Accumulated $\%$ & Sum & Variance $\%$ & Accumulated $\%$ \\
\hline 1 & 2.973 & 49.551 & 49.551 & 2.973 & 49.551 & 49.551 & 1.645 & 27.412 & 27.412 \\
\hline 2 & 1.053 & 17.547 & 67.099 & 1.053 & 17.547 & 67.099 & 1.508 & 25.126 & 52.538 \\
\hline 3 & 0.656 & 10.936 & 78.035 & 0.656 & 10.936 & 78.035 & 1.065 & 17.752 & 70.290 \\
\hline 4 & 0.585 & 9.746 & 87.780 & 0.585 & 9.746 & 87.780 & 1.049 & 17.490 & 87.780 \\
\hline 5 & 0.396 & 6.598 & 94.378 & & & & & & \\
\hline 6 & 0.337 & 5.622 & 100.000 & & & & & & \\
\hline
\end{tabular}

Table 10. Matrix of rotated components of internal influencing elements.

\begin{tabular}{|c|c|c|c|c|}
\hline \multirow{2}{*}{ Influencing element } & \multicolumn{4}{|c|}{ Component } \\
\hline & 1 & 2 & 3 & 4 \\
\hline Degree of effect of attention attached by senior executives & 0.279 & 0.101 & 0.097 & 0.928 \\
\hline Degree of effect of quality of logistics risk management staffs & 0.886 & 0.142 & 0.128 & 0.178 \\
\hline Degree of effect of logistics management level & 0.817 & 0.290 & 0.084 & 0.207 \\
\hline Degree of effect of improvement of logistics risk management institutions & 0.224 & 0.851 & 0.068 & 0.295 \\
\hline Degree of effect of advancement of logistics risk management technology & 0.220 & 0.785 & 0.365 & -0.121 \\
\hline Degree of effect of logistics development phase & 0.130 & 0.227 & 0.946 & 0.109 \\
\hline
\end{tabular}


technology equipment to reach its risk management goal. In terms of phase of logistics development, this factor links closely with macroscopic environment within a country, thus any attempt to change should consider in the prospect of industry as a whole. As for attention attached by senior executives, it refers to enhancement of senior executives' understanding of logistics risk early warning and cementing of their attention attached on it, which can be realized by dissecting successful cases of enterprise logistics risk early warning, through which management can perceive the interests brought by enterprise logistics risk early warning.

\section{Conclusions and Suggestions}

Based on questionnaire survey, this research analyzes fundamental status and influencing elements of enterprise logistics risk early warning of manufacturing industry in Beijing area. Concluded from above discussions, 1) present status of enterprise logistics risk early warning of manufacturing industry in Beijing area is not ideal, because of insufficient attention paid and lack of professional knowledge, which haven't drawn much attentions from whatever first line staffs or management; 2) the external influencing elements of enterprise logistics risk early warning includes political-legal environment factor, natural environment factor and economic environment factor, and internal influencing elements are consist of logistics management soft technology, logistics management hard technology, phase of logistics development and attention attached by senior executives. The effect of internal influencing elements outweighs that of external counterparts.

Suggestions according to above conclusions are proposed as follows. 1) To radically shift the adverse situation of enterprise logistics risk early warning, firstly, understanding what enterprise logistics risk management is should be put onto an agenda, which is the basis. And secondly, trainings on fundamental knowledge and skills of enterprise logistics risk early warning should be enforced to make that working process understood by related staffs, who can identify and evaluate enterprise logistics risk and early warning indexes; 2) during the enterprise logistics risk early warning working process, management's perception of risk should be enhanced as well. As for external influencing elements, mends of related political-legal items should be put on more emphasis. To internal ones, more importance should be attached to improvement of logistics management level.

Although manufacturing industry in Beijing area is selected as research object in this research, to some extent, the conclusions and suggestions are valuable to the practice of enterprise logistics risk early warning of
China's manufacturing industry, even other industries as well.

\section{REFERENCES}

[1] M. Liu, "The Early Warning Management of Logistics Service Risk Based on Fuzzy Comprehensive Evaluation," 2007 IEEE International Conference on Grey Systems and Intelligent Services, Nanjing, 18-20 November 2007, pp. 983-987. doi:10.1109/GSIS.2007.4443419

[2] Q. Cheng, "Logistics Service Operation Risk and Its Early Warning Management," Journal of Wuhan University of Technology (Social Science Version), Vol. 23, No. 5, 2010, pp. 636-640

[3] Y. S. Liu, B. Tang and L. Yang, "The Research on Risk Early Warning Index System of Logistics Corporation," Railway Transportation and Economy, Vol. 2, 2010, pp. 74-76.

[4] L. H. Liu, "Design and Assessment on Index System of Enterprise Logistics Outsourcing Risk Early Warning," Logistics technology, Vol. 24, No. 9, 2005, pp. 107-109.

[5] G. B. Xu, "Index System of Enterprise Logistics Outsourcing Risk Early Warning Based on Case Reasoning," Logistics Technology, Vol. 26, No. 1, 2007, pp. 22-24.

[6] Y. T. Hong and X. J. Li, "The Formulation of Index System of Enterprise Logistics Outsourcing Risk Early Warning and Analysis and Assessment on Outsourcing Risk," Logistics Technology, Vol. 27, No. 9, 2008, pp. 101-104.

[7] D. H. Yang and D. W. Yin, "Design and Assessment on Index System of Adverse Logistics Risk Early Warning," China Market, Vol. 2, 2008, pp. 98-99.

[8] W. Y. Duan, "The Research on Corporate Adverse Logistics Risk Early Warning Management," Daqing Petroleum Institute, Daqing, 2010.

[9] M. Q. Zhang and Y. Zhou, "The Research on Logistics Activity Risk Early Warning and Prevention Strategy," Logistics Technology, Vol. 27, No. 4, 2008, pp. 49-51.

[10] K. Xie, J. Liu, H. Peng, et al., "Early-Warning Management of Inner Logistics Risk in SMEs Based on LabelCard System," Production Planning \& Control: The Management of Operations, Vol. 20, No. 4, 2009, pp. 306-319.

[11] Y. S. Liu and Y. Wang, "The Research on Mechanism of Enterprise Logistics Risk Early Warning: Based on Supply Chain Management," Economic Issues, Vol. 9, 2009, pp. $78-80$.

[12] Z. Cheng and P. Zhang, "Study on Logistics Equilibrium Early Warning Control of Steel Corporation Industrial Port," 2010 IEEE International Conference on Advanced Management Science, Chengdu, 9-11 July 2010, pp. 572574. doi:10.1109/ICAMS.2010.5553173

[13] L. Ji, "The Research on Index System of Enterprise Logistics Risk Early Warning: Based on Supply Chain Management," Beijing Wuzi University, Beijing, 2010. 